\title{
ESSAY
}

\section{The Creation of a Review Mechanism for the UN Convention against Transnational Organized Crime and Its Protocols}

\author{
By Cecily Rose*
}

In November 2000, the United Nations General Assembly adopted the United Nations Convention Against Transnational Organized Crime ${ }^{1}$ (UNTOC or Convention) and its three protocols on human trafficking, migrant smuggling, and firearms. ${ }^{2}$ These instruments are the product of three years of diplomatic negotiations, and they represent a substantial contribution to international lawmaking in the area of transnational criminal law. UNTOC has attracted almost universal participation, with 190 states parties at present. ${ }^{3}$ Nearly two decades after the adoption of these instruments, however, remarkably little is known about whether states parties have implemented UNTOC and its protocols in their national legislation, whether they enforce such legislation, and whether they make use of UNTOC's provisions concerning international cooperation (e.g., extradition and mutual legal assistance). In other words, the influence of these instruments in practice remains largely unknown. ${ }^{4}$

UNTOC created a Conference of the Parties which is responsible for reviewing the implementation of UNTOC and its protocols, but its efforts to gather information on compliance faltered in the years immediately following UNTOC's entry into force in September 2003. When the Conference of the Parties shifted its attention to the creation of a formal review mechanism in the late 2000s, years of controversy followed. States parties disagreed, in

* Assistant Professor, Grotius Centre for International Legal Studies, Leiden University. Many thanks to Elizabeth Hartley for her research assistance and to Alexandra Utech (J.D. 2020) for her assistance in preparing this Essay for publication.

${ }^{1}$ United Nations Convention Against Transnational Organized Crime and the Protocols Thereto, Nov. 15, 2000, 2225 UNTS 209 (entered into force Sept. 29, 2003) [hereinafter UNTOC].

2 Protocol to Prevent, Suppress, Punish Trafficking in Persons, Especially Women and Children, Supplementing the United Nations Convention Against Transnational Organized Crime, Nov. 15, 2000, 2237 UNTS 319 (entered into force Dec. 25, 2003) [hereinafter Trafficking Protocol]; Protocol Against the Smuggling of Migrants by Land, Sea and Air, Supplementing the United Nations Convention Against Transnational Organized Crime, Nov. 15, 2000, 2241 UNTS 507 (entered into force Jan. 28, 2004) [hereinafter Smuggling Protocol]; Protocol Against the Illicit Manufacturing of and Trafficking in Firearms, Their Parts and Components and Ammunition, Supplementing the United Nations Convention Against Transnational Organized Crime, May 31, 2001, 2326 UNTS 208 (entered into force June 3, 2005) [hereinafter Firearms Protocol].

${ }^{3}$ Ratification levels for the Protocols are lower and varied. The Trafficking Protocol has 174 states parties, the Smuggling Protocol has 149 states parties, and the Firearms Protocol has 118 states parties. For an analysis of the ratification level of the Smuggling Protocol, see Andreas Schloenhardt \& Hamish MacDonald, Barriers to Ratification of the United Nations Protocol Against the Smuggling of Migrants, 7 AsIAN J. INT'L L. 13 (2017).

${ }^{4}$ Neil Boister, The Cooperation Provisions of the UN Convention Against Transnational Organised Crime: A “Toolbox” Rarely Used?, 16 InT'L Crim. L. ReV. 39 (2016). 
particular, about whether civil society should be permitted to participate in the Review Mechanism and how it should be funded. By the time the Conference of the Parties finally agreed on the creation of a Review Mechanism in October 2018, states parties had spent more years negotiating the contours of this treaty monitoring body than they had spent negotiating the treaties themselves.

This Essay seeks to explain why the creation of a Review Mechanism for UNTOC proved to be so controversial, and to offer some insights into the compromise ultimately struck by the Conference of the Parties. In exploring the history and features of this treaty monitoring body, this Essay compares it primarily with the Review Mechanism for the United Nations Convention against Corruption (UNCAC). ${ }^{5}$ This comparison is especially appropriate and revealing not because UNCAC's Review Mechanism represents an ideal treaty monitoring system, but rather because UNTOC and UNCAC are very closely related to each other and UNCAC's Review Mechanism served as the most relevant model for the development of UNTOC's Review Mechanism. This comparison is essential for fully understanding UNTOC's Review Mechanism because states' experiences with and perceptions of UNCAC's Review Mechanism very much shaped opinions about what a Review Mechanism for UNTOC should (or should not) look like. The controversies surrounding both review mechanisms reflect, at least in part, the relatively low priority of criminal justice within the United Nations system, and the general reluctance of states to submit their criminal justice systems to external scrutiny, whether by civil society or other states parties. In addition, negotiations were further complicated by the general absence of treaty-monitoring bodies in the field of transnational criminal law and the precedent set by UNCAC's Review Mechanism, in particular. The compromises reached by UNTOC's Conference of the Parties facilitated an agreement on the creation of a Review Mechanism at long last, but they also resulted in rules on transparency and inclusiveness that will likely hamper the normative legitimacy of this body.

By recounting the delays and controversies leading up to the creation of the UNTOC Review Mechanism, this Essay seeks to contribute to the study of treaty compliance, in particular compliance with transnational criminal law treaties. The existence and working methods of treaty monitoring bodies have great relevance for measuring treaty compliance, for without these bodies, it can be difficult even to identify the key compliance challenges, let alone address them. States and international organizations have therefore created treaty monitoring bodies in a wide range of areas across the field of public international law, from human rights law, to environmental law, to arms control law. These treaty monitoring bodies vary significantly with respect to their mandates and design, and it cannot be said that an ideal model exists for treaty monitoring bodies. While a relatively extensive network of transnational criminal law treaties has emerged since World War II, many of these treaties do not make any provision for the creation of a formal treaty monitoring body-a phenomenon which, in and of itself, is noteworthy. UNTOC and UNCAC are two of the exceptions, and their working methods and output deserve scrutiny.

This Essay begins in Part I by recounting the Conference of the Parties' early, informal attempts at treaty monitoring. It then describes in Part II the major points of controversy

\footnotetext{
${ }^{5}$ United Nations Convention Against Corruption, Oct. 31, 2003, 2349 UNTS 41 (entered into force Dec. 14, 2005) [hereinafter UNCAC].
} 
that arose during the negotiation of a formal review mechanism. Parts III and IV outline the main contours of the UNTOC Review Mechanism and offer some explanations for the delays and controversies surrounding the negotiation of this body.

\section{The Conference of the Parties’ Early Attempts at Treaty Monitoring}

UNTOC and its protocols aim to combat transnational organized crime by requiring states parties to criminalize certain conduct in their domestic legislation and by facilitating international cooperation between states in the investigation and prosecution of such crimes. UNTOC specifically requires states parties to criminalize participation in an organized criminal group (Article 5), as well as money laundering (Article 6) and the bribery of public officials (Article 8). The drafters failed to agree on a comprehensive definition of organized crime, and instead limited UNTOC's scope of application to the involvement of "organized criminal groups" in "serious crime" with a transnational character. ${ }^{6}$ This approach has the advantage of making UNTOC flexible enough to apply to a wide range of organized criminal groups, but has also been criticized for being both under- and overinclusive. ${ }^{7}$ Minor criminal groups may fall within this definition, as "organized criminal groups" may consist of just three persons, and "serious crimes" refers to offenses punishable by a maximum deprivation of liberty of four or more years. ${ }^{8}$ Meanwhile, terrorist groups that act with ideological or other motives, rather than material motives, may fall outside UNTOC's scope, as UNTOC defines organized criminal groups as acting with the goal of financial or material benefit. ${ }^{9}$

The three protocols further require the criminalization of trafficking in persons, ${ }^{10}$ the smuggling of migrants, ${ }^{11}$ and the illicit manufacturing of and trafficking in firearms, their parts and components, and ammunition ${ }^{12}$ - terms which the Protocols explicitly define. In order for the Protocols to be used as the basis for international cooperation, the offenses must be "transnational in nature" and must involve an organized criminal group, as defined in UNTOC. ${ }^{13}$ Although these treaties adopt a predominantly criminal law approach to these

\footnotetext{
${ }^{6}$ UNTOC, supra note 1, Article 2(a) defines "organized criminal group" as "a structured group of three or more persons, existing for a period of time and acting in concert with the aim of committing one or more serious crimes or offences established in accordance with this Convention, in order to obtain, directly or indirectly, a financial or other material benefit." UNTOC Article 2(c) defines a "structured group" as a "group that is not randomly formed for the immediate commission of an offence and that does not need to have formally defined roles for its members, continuity of its membership or a developed structure."

${ }^{7}$ Neil Boister, An Introduction to Transnational Criminal LaW 132-34 (2018).

${ }^{8} \mathrm{Id}$.

${ }^{9} \mathrm{Id}$.

${ }^{10}$ Trafficking Protocol, supra note 2, Article 3(a) defines "trafficking in persons" as "the recruitment, transportation, transfer, harbouring or receipt of persons, by means of the threat or use of force or other forms of coercion, of abduction, of fraud, of deception, of the abuse of power or of a position of vulnerability or of the giving or receiving of payments or benefits to achieve the consent of a person having control over another person, for the purpose of exploitation. Exploitation shall include, at a minimum, the exploitation of the prostitution of others or other forms of sexual exploitation, forced labour or services, slavery or practices similar to slavery, servitude or the removal of organs."

${ }^{11}$ Smuggling Protocol, supra note 2, Article 3(a) defines the "smuggling of migrants" as "the procurement, in order to obtain, directly or indirectly, a financial or other material benefit, of the illegal entry of a person into a State Party of which the person is not a national or a permanent resident."

${ }^{12}$ Firearms Protocol, supra note 2, Art. 3(a)-(e).

13 Trafficking Protocol, supra note 2, Art. 4; Smuggling Protocol, supra note 2, Art. 4; Firearms Protocol, supra note 2, Art 4(1); UNTOC, supra note 1, Arts. 2(a), 3(2).
} 
phenomena, they also address, to a lesser extent, prevention and the protection of victims of trafficking and smuggled migrants. The Trafficking Protocol, for example, has relatively weak provisions concerning the protection of victims. States parties are not obliged to refrain from prosecuting the victims, and they also are not required to permit victims to remain on their territory, whether temporarily or permanently. ${ }^{14}$

When states concluded the Convention and its Protocols in 2000, they left open the issue of a review mechanism. Article 32 of UNTOC leaves the creation of a review mechanism to the discretion of the Conference of the Parties, a plenary body consisting of all 190 states parties to the Convention. The Conference of the Parties is obliged to engage in capacity building among states parties and to promote and review the Convention's implementation, but Article 32 does not specify how it should do so. ${ }^{15}$ The provision simply provides that the Conference of the Parties shall gather information and assess implementation problems "through such supplemental review mechanisms as may be established" by it. ${ }^{16}$

The travaux préparatoires reveal that some delegations were concerned about confidentiality in the context of treaty monitoring, in particular how a treaty monitoring body would deal with "sensitive operational information," such as information concerning ongoing investigations. ${ }^{17}$ The involvement of nongovernmental organizations (NGOs) was also a point of concern for some delegations. ${ }^{18}$ Instead of resolving these issues during the negotiations, the delegations deferred a "thorough discussion" of them until after the entry into force of UNTOC and its Protocols. ${ }^{19}$ But an interpretive note to Article 32 memorializes delegations' concerns about confidentiality by indicating that the Conference of the Parties "should give due regard to the need to preserve the confidentiality of certain information, given the nature of the fight against transnational organized crime." 20 Yet, given both the text of Article 32 and the reality of treaty monitoring in general, maintaining the confidentiality of information about ongoing operations or investigations is unlikely to be problematic. Article 32 specifically mentions only the review of implementation, not enforcement. While a review of enforcement could conceivably cover sensitive ongoing operations or investigations, a review of legislative implementation would not. Moreover, treaty monitoring bodies typically focus not on states parties' ongoing investigations, but on their existing laws and policies, and sometimes also existing judgments by domestic courts. In this author's view, therefore, this interpretive note appears to reflect delegations' larger resistance to a review mechanism, rather than well-founded concerns about the release of confidential information through such a mechanism.

${ }^{14}$ Trafficking Protocol, supra note 2, Art. 7(1).

${ }^{15}$ UNTOC, supra note 1, Article 32(1) provides that "A Conference of the Parties to the Convention is hereby established to improve the capacity of States Parties to combat transnational organized crime and to promote and review the implementation of this Convention."

${ }^{16}$ UNTOC, supra note 1, Article 32(4) provides that "the Conference of the Parties shall acquire the necessary knowledge of the measures taken by States Parties in implementing this Convention and the difficulties encountered by them in doing so through information provided by them and through such supplemental review mechanisms as may be established by the Conference of the Parties."

${ }^{17}$ UnOdC, TRaVauX PrÉparatoires of the Negotiations for the Elaboration of the United Nations Convention Against Transnational Organized Crime and the Protocols Thereto, at 269 n. 2, 270 n. 3, 274 n. 10, UN Sales No. E.06.V.5 (2006).




In theory, Article 32 allows for the possibility that the Conference of the Parties could gather and analyze information about implementation itself, without the help of a supplementary review mechanism. In practice, however, it would be unmanageable for the Conference of the Parties to carry out an in-depth review of implementation by nearly two hundred states parties, as it meets only biennially for a week at a time. ${ }^{21}$ Nevertheless, in its early years, the Conference of the Parties did indeed attempt to collect and evaluate information about implementation itself, without such a supplementary body. Between 2004 and 2006, the Conference of the Parties, with the support of the Secretariat of the United Nations Office on Drugs and Crime (UNODC), tried to collect information itself through lengthy paper-based questionnaires that states parties were meant to complete about their domestic implementation, international cooperation, technical assistance needs, and the protection of victims. ${ }^{22}$ But this early attempt at treaty monitoring was relatively unsuccessful, due in part to low response rates to the questionnaires. ${ }^{23}$ In the first reporting cycle, just under half of the states parties completed the questionnaire, and the response rate was even lower for the second reporting cycle (about one third of states completed the questionnaire).

The low response rates have been generally attributed to the burden involved in completing the questionnaires, which states parties perceived as overly complicated and as involving too much coordination among national authorities. ${ }^{24}$ Some states parties may have also lacked the capacity needed to collect and process the required information. ${ }^{25}$ In addition, a general "reporting fatigue" may have also been a factor at play, given the many reporting obligations that states have with respect to treaties in other branches of public international law (e.g., human rights and environmental law treaties). ${ }^{26}$ The persuasiveness of these explanations is open to question, however, as states parties eventually went on to design a review mechanism that imposes reporting obligations on states parties that are arguably just as onerous as those in these initial questionnaires. Moreover, each state party also bears an obligation to act as a peer reviewer, as will be explained below. These low response rates may have further reflected a general lack of interest

${ }^{21}$ UNODC, Rules of Procedure for the Conference of the Parties to the United Nations Convention Against Transnational Organized Crime, Rule 3 (2015).

22 Conference of the Parties to the United Nations Convention Against Transnational Organized Crime, Development of Tools to Gather Information from States on the Implementation of the United Nations Convention Against Transnational Organized Crime and each of the Protocols thereto: Report of the Secretariat, UN Doc. CTOC/COP/2008/2, Annex (July 25, 2008).

${ }^{23}$ Conference of the Parties to the United Nations Convention Against Transnational Organized Crime, Relaunching the Conference of the Parties: Note by the Executive Director, paras. 8-12, UN Doc. CTOC/COP/2006/10 (Oct. 4, 2006). The information received by the Secretariat through these paper-based questionnaires also posed problems with respect to legibility, the reliability of the data, and the organization of information. Conference of the Parties to the United Nations Convention Against Transnational Organized Crime, Update on the Development of the Omnibus Survey Software to Collect Information on the Implementation of the United Nations Convention Against Transnational Organized Crime and the Protocols Thereto, Note by the Secretariat, para. 3, UN Doc. CTOC/COP/2012/CRP.2 (Aug. 23, 2012) [hereinafter Omnibus Survey Software Update].

${ }^{24}$ Id., paras. 1-17; Conference of the Parties to the United Nations Convention Against Transnational Organized Crime, Report of the OSCE-UNODC Workshop on the "Information-Gathering Mechanism to Support and Facilitate the Work of the Conference of the Parties to the United Nations Convention Against Transnational Organized Crime,” para. 31, UN Doc. CTOC/COP/2006/CRP.1 (Aug. 14, 2006).

${ }^{25} \mathrm{Id}$.

${ }^{26} \mathrm{Id}$. 
at that point in participating in any sort of treaty monitoring effort, and a lack of consensus about how such monitoring should be carried out.

The Conference of the Parties' early attempts at treaty monitoring were supported by the UNODC Secretariat, which wrote individual letters to states parties found to be in noncompliance with provisions of the treaty. ${ }^{27}$ This approach to monitoring and follow-up also elicited a low response rate and the Secretariat acknowledged that the approach was rather negative and noncomprehensive, in that the Secretariat's letters focused only on points of noncompliance, rather than the overall picture of compliance. ${ }^{28}$ The Secretariat also considered its letter-writing approach to be inefficient, although targeted letter-writing is arguably less time-consuming (and therefore more efficient) than lengthy review reports covering compliance as well as noncompliance. ${ }^{29}$ But ad hoc letters may indeed represent an ineffective approach to treaty monitoring, when undertaken in the absence of an agreed upon system or process for reviewing implementation.

By 2007 the Conference of the Parties had abandoned the questionnaires and the letters, and was instead engaged in an effort to introduce a computer-based self-assessment checklist. ${ }^{30}$ But due in part to limited resources, the Secretariat was slow to make this checklist available in the UN's six official languages and to finalize the software. ${ }^{31}$ By 2010, the Conference of the Parties had begun to shift away from these informal, ad hoc attempts at treaty monitoring, and instead focused its attention on developing a formal supplementary review mechanism. The next part details the controversies that followed.

\section{Points of Controversy During Negotiations}

In negotiating a review mechanism for UNTOC, states parties struggled for years to resolve two major points of controversy, namely, the participation of civil society in the review mechanism, and the financing of the review mechanism. To a lesser extent, the burdensomeness of the review mechanism was also a point of controversy. The confidentiality of sensitive operational information was, however, not a point of explicit concern, despite the interpretative note to Article 32 and the apparent importance of this issue to certain delegations during the negotiations of the treaty. In the early phases of negotiations, states parties also discussed whether or not to create a review mechanism at all, ${ }^{32}$ and they surveyed the different

${ }^{27}$ Conference of the Parties to the United Nations Convention Against Transnational Organized Crime, Possible Mechanisms to Review Implementation of the United Nations Convention Against Transnational Organized Crime and the Protocols Thereto, Note by the Secretariat, para. 8, UN Doc. CTOC/COP/2008/3 (Aug. 26, 2008).

${ }^{28} I d$., para. 9.

${ }^{29}$ Id. ("With 146 States parties and a scope of four instruments, the task of identifying gaps in the implementation of individual provisions and addressing States individually with respect to each of those gaps may become extremely time- consuming.").

${ }^{30}$ Omnibus Survey Software Update, supra note 23, paras. 3-4.

31 Id., paras. 9-13; Conference of the Parties to the United Nations Convention Against Transnational Organized Crime, Report of the Conference of the Parties to the United Nations Convention Against Transnational Organized Crime on its Fourth Session, para. 69, UN Doc. CTOC/COP/2008/19 (Dec. 1, 2008); Conference of the Parties to the United Nations Convention Against Transnational Organized Crime, Res. 5/5, Review of the Implementation of the United Nations Convention Against Transnational Organized Crime and the Protocols Thereto, pmbl. para. 4, para. 6.

32 Conference of the Parties to the United Nations Convention Against Transnational Organized Crime, Compilation of Comments and Views Received from States on Possible Mechanisms to Review Implementation of the United Nations Convention Against Transnational Organized Crime and the Protocols 
approaches to treaty monitoring, in particular review by independent experts, and review by peers. ${ }^{33}$ But the existence and basic character of the review mechanism were not the central controversies during the negotiations. For the most part, states parties seem to have agreed that the Conference of the Parties should create a review mechanism, and that the mechanism should involve peer review, along the lines of the Review Mechanism for the United Nations Convention Against Corruption.

The participation of civil society in the review mechanism proved to be highly controversial, despite the fact that the Protocols explicitly mention the role of civil society in implementing domestic measures, in cooperation with states parties. ${ }^{34}$ Even though the drafters of the Convention and its Protocols envisioned civil society playing a role in preventing human trafficking and protecting victims of human trafficking, ${ }^{35}$ some states parties (e.g., Cuba, Egypt, Malaysia, Singapore, and South Africa) were very much opposed to civil society taking part in what they saw as a solely "intergovernmental" review process. ${ }^{36}$ States debated, in particular, the participation of civil society in the Conference of the Parties' substantive meetings about implementation, and whether civil society should be permitted to provide information to peer reviewers during country reviews. Some states parties reportedly objected to involving civil society in the review process because of resistance to giving them a voice in criticizing their track records in combating organized crime. ${ }^{37}$ Such resistance may reflect certain states' broader disinterest in or opposition to international oversight of their criminal

Thereto: Note by the Secretariat, paras. 5-7, UN Doc. CTOC/COP/WG.1/2009/2 (Sept. 2, 2009) (China, in particular, considered that a review mechanism was not currently needed).

${ }^{33}$ Conference of the Parties to the United Nations Convention Against Transnational Organized Crime, Possible Mechanisms to Review Implementation of the United Nations Convention Against Transnational Organized Crime and the Protocols Thereto: Comparative Analysis of Existing Review Mechanisms Under Other International Instruments: Note by Secretariat, UN Doc. CTOC/COP/WG.1/2010/2 (Dec. 29, 2009) [Comparative Analysis of Existing Review Mechanisms].

34 See Meeting to Explore All Options Regarding an Appropriate and Effective Review Mechanism for the United Nations Convention Against Transnational Organized Crime and the Protocols thereto, Compilation of Contributions Received from States on All Options Regarding an Appropriate and Effective Review Mechanism for the UNTOC and the Protocols Thereto, Non-paper Transmitted by the Secretariat, paras. 9, 25, 30-50, 91, UN Doc. CTOC/COP/WG.8/2016/CRP.1 (June 3, 2016) [hereinafter 2016 Compilation]. See also Open-Ended Intergovernmental Working Group on the Review of the Implementation of the United Nations Convention Against Transnational Organized Crime and the Protocols Thereto, Terms of Reference for a Review Mechanism or Mechanisms, Guidelines for Governmental Experts and a Blueprint for the Country Review Reports: Proposals and Initiatives of States Parties and Signatories: Report of the Secretariat, para. 17, UN Doc. CTOC/COP/WG.5/2011/CRP.1 (May 10, 2011).

35 Trafficking Protocol, supra note 2, Art. 6(3) ("Each State Party shall consider implementing measures to provide for the physical, psychological and social recovery of victims of trafficking in persons, including, in appropriate cases, in cooperation with non-governmental organizations, other relevant organizations and other elements of civil society ...."); Art. 9(3) ("Policies, programmes and other measures established in accordance with this article [on prevention of trafficking in persons] shall, as appropriate, include cooperation with non-governmental organizations, other relevant organizations and other elements of civil society."); Art. 10(2) (training for law enforcement, immigration and other relevant officials in the preventing of trafficking in persons "should encourage cooperation with non-governmental organizations, other relevant organizations and other elements of civil society"). Smuggling Protocol, supra note 2, Art. 4(2).

${ }^{36}$ Mark Shaw, Ugljesa Zvekic, Peter Gastrow \& Julia Stanyard, What to Make of the New UNTOC Review Mechanism?, Glob. Initiative Against Transnat'l Organized Crime (Nov. 2, 2018), at https://globalinitiative. net/untoc-review-mechanism.

${ }^{37}$ Mark Shaw \& Julia Stanyard, It's Now or Never: Will a Review Mechanism for the UN Convention Against Transnational Organized Crime Finally be Achieved This Week at the Ninth Session of the Conference of the Parties?, Glob. Initiative Against Transnat'l Organized Crime (Oct. 14, 2018), at https://globalinitiative. net/untoc-review-mechanism-now-or-never. 
justice systems, particularly by NGOs that are perceived as "Western" and/or in alignment with "Western States." 38 Some states also reportedly claimed that the inclusion of civil society was unnecessary because of a lack of civil society groups focused on organized crime, a claim that is factually inaccurate, in light of, for example, the Global Initiative Against Transnational Organized Crime. ${ }^{39}$

These objections to the inclusion of civil society in a review mechanism for UNTOC can only be fully understood in light of the long-standing controversy about the role of civil society in UNCAC's Review Mechanism. UNCAC itself acknowledges the role of civil society in combating corruption, as it includes an entire provision on civil society's role in preventing corruption. ${ }^{40}$ Moreover, the Rules and Procedures of UNCAC's Conference of States Parties indicate that NGOs with observer status may attend plenary meetings of the Conference, and any mechanism or body established by it. ${ }^{41}$ But the Conference of the States Parties has not been able to agree on whether civil society should be allowed to attend the meetings of the Implementation Review Group (IRG), and has thus far agreed only on the participation of civil society in briefings held at the margins of the IRG's sessions. ${ }^{42}$ While some states parties have viewed this so-called "Marrakesh consensus" as the starting point for increased civil society involvement in the review process, other states parties have viewed it as the end point. ${ }^{43}$ Civil society has, however, participated in the vast majority of the country reviews that have taken place under UNCAC's Review Mechanism. ${ }^{44}$

The controversy surrounding civil society's role in the review process for both UNTOC and UNCAC forms a stark contrast with civil society's well-established role in the review of states' human rights obligations, both by treaty bodies and by the Human Rights Council, which carries out Universal Periodic Reviews. ${ }^{45}$ In the context of the human rights treaty bodies, for

${ }^{38}$ See 2016 Compilation, supra note 34, para. 17.

${ }^{39}$ Shaw \& Stanyard, supra note 37.

${ }^{40}$ UNCAC, supra note 5, Art. 13.

${ }^{41}$ UNODC, Rules of Procedure of the Conference of States Parties to the United Nations Convention Against Corruption, Rule 17(3) (2007) ("Without taking part in the adoption of decisions on substantive and procedural matters, whether by consensus or by vote, at the Conference, such non-governmental organizations may: (a) attend plenary meetings of the Conference; (b) Upon the invitation of the President and subject to the approval of the Conference, make oral statements or provide written reports at such meetings through a limited number of representatives or questions relating to their activities; and (c) Receive the documents of the Conference."); Rule 2(2) ("These rules shall apply, mutatis mutandis, to any mechanism or body that the Conference may establish in accordance with article 63 of the Convention, unless it decides otherwise."). Conference of the States Parties to the United Nations Convention Against Corruption, Implementation Review Group, "Legal Opinion from the Office of Legal Affairs: Note by the Secretariat," UN Doc. CAC/COSP/IRG/2010/9 (Aug. 26, 2010). Conference of the States Parties to the United Nations Convention Against Corruption, Civil Society Engagement in the Implementation of the United Nations Convention Against Corruption: Document Submitted by Finland, UN Doc. CAC/COSP/2015/CRP.3 (Sept. 22, 2015) [hereinafter Civil Society Engagement].

${ }^{42}$ UNCAC Conference of States Parties, Res. 4/6, Non-governmental Organizations and the Mechanism for the Review of Implementation of the United Nations Convention Against Corruption (Oct. 2011).

${ }_{43}$ Civil Society Engagement, supra note 41, at 6, 20.

${ }^{44}$ UNCAC Implementation Review Group, Progress Report on the Implementation of the Mandates of the Implementation Review Group, para. 29, UN Doc. CAC/COSP/IRG/2017/CRP.11 (Oct. 30, 2017).

45 Tom Obokata, Transnational Organized Crime in International Law 215-16 (2010); Ben Schokman \& Phil Lynch, Effective NGO Engagement with the Universal Periodic Review, in Human Rights AND THE Universal Periodic Review: Rituals and Ritualism (Hilary Charlesworth \& Emma Larking eds., 2015); Andrew Clapham, UN Human Rights Reporting Procedures: An NGO Perspective, in The Future of UN Human Rights Treaty Monitoring (Philip Alston \& James Crawford eds., 2000). 
example, civil society may submit written reports to be considered by the treaty body alongside the state's report, and may attend and contribute to the public sessions of the treaty body. ${ }^{46}$ This comparison between monitoring mechanisms is useful because it shows that the role of civil society in review processes very much depends on the context. Even though human rights treaty monitoring can involve the review of politically sensitive issues for the states under review, civil society's role in the review processes is nevertheless well-established and also well-accepted. Resistance to civil society participation in treaty monitoring therefore cannot be seen as a given where politically sensitive issues are under review. Rather, opposition to the participation of civil society in the context of the UNTOC and UNCAC Review Mechanisms seems to reflect a broader and long-standing resistance to the transnational regulation of criminal justice issues, as will be discussed below.

With respect to the issue of funding, some states favored using UN regular budget funds to support UNTOC's Review Mechanism (e.g., China, Iran, Pakistan, Russia, and South Africa). ${ }^{47}$ Other states that are committed to containing the growth of the UN's regular budget (e.g., Canada, Japan, the United States, and the United Kingdom), were opposed to this, and supported only voluntary contributions. ${ }^{48}$ The costliness of UNCAC's Review Mechanism undoubtedly cast a shadow over negotiations with respect to UNTOC's Review Mechanism. ${ }^{49}$ UNCAC's Review Mechanism involves week-long visits by peer reviewers and officials from UNODC's Secretariat to the country under review. In addition, staff from UNODC's Secretariat have been involved in the preparation of the lengthy country reports that follow these country visits. The human and financial resources involved in conducting country visits and then producing country reports are, of course, considerable, and some states were evidently uninterested in replicating such a resource-intensive model with respect to UNTOC.

Finally, the potential burdensomeness of a review mechanism for UNTOC also featured in negotiations, but to a lesser extent than the issues of civil society participation and funding. The United States, in particular, emphasized the burden involved in requiring government officials to complete self-assessment questionnaires. ${ }^{50}$ The United States argued that the effort devoted by government officials to reporting on implementation detracts from their efforts to actually implement the Convention. Treaty monitoring bodies undoubtedly impose burdens on states parties, as the United States has stressed, but whether those costs outweigh the benefits of such treaty bodies is up for debate. Regardless, developed countries, in particular the United States, are generally very well-positioned to devote the necessary

${ }^{46}$ Office of the High Commissioner for Human Rights, Working with the United Nations Human Rights Programme: A Handbook for Civil Society, 46-57, UN Doc. HR/PUB/06/10/Rev.1 (2008).

${ }^{47}$ Mark Shaw, Divisions Thwart UNTOC Review Process: Is the Idea of a Review Mechanism for the UN Convention Against Transnational Crime Dead?, Glob. Initiative Against Transnat'l Organized Crime (May 4, 2018), at https://globalinitiative.net/un-toc_watch13.

48 Shaw \& Stanyard, supra note 37.

49 The first two years of the second cycle for UNCAC's Review Mechanism were projected to cost a total of nearly USD 11 million. Implementation Review Group of the United Nations Convention Against Corruption, Projected Costs for the Functioning of the Second Cycle of the Mechanism for the Review of Implementation of the United Nations Convention Against Corruption, 9-10, UN Doc. CAC/COSP/IRG/2015/CRP.6 (May 19, 2015).

${ }^{50}$ Conference of the Parties to the United Nations Convention Against Transnational Organized Crime, Compilation of Comments and Views Received from States on All Options Regarding an Appropriate and Effective Review Mechanism for the United Nations Convention Against Transnational Organized Crime and the Protocols Thereto: Note by the Secretariat, para. 104, UN Doc. CTOC/COP/WG.8/2015/2 (Aug. 5, 2015). 
human and financial resources to a review process, whereas many developing countries encounter great difficulties in coping with such reporting requirements.

\section{The Review Mechanism's Salient Features}

After approximately ten years of negotiations that some thought would never reach a successful conclusion, states parties finally agreed to create a review mechanism in October 2018. The result is a compromise that leaves UNTOC with a weaker treaty monitoring body than UNCAC's Review Mechanism, which is itself weaker than the OECD Working Group on Bribery, the monitoring body for the OECD Anti-Bribery Convention. ${ }^{51}$ The sixteen principles that guide the structure and work of the UNTOC Review Mechanism are themselves strong indications of the tensions embodied in this compromise. ${ }^{52}$ On the one hand, the principles indicate that the states parties aspire to create a Review Mechanism that is "transparent," "inclusive," and "impartial." 53 These modifiers signal an awareness of the importance of including stakeholders and publishing evaluations-aims which are not entirely achieved by the compromise. On the other hand, states parties' anxieties about the Review Mechanism are evident in a long list of other qualifiers, which stipulate that the Review Mechanism must be "efficient," "non-intrusive," "non-adversarial," "non-punitive," and "inter-governmental"; must not produce any form of ranking or interfere in the domestic affairs of states parties; and must respect state sovereignty. ${ }^{54}$

This list of qualifiers suggests strong resistance among states parties to the creation of a review mechanism that could substantially pressure or coerce states parties into improving compliance. The "naming and shaming" approach associated with human rights treaty bodies, for example, is geared in part toward allowing NGOs to pressure states to improve their compliance with human rights obligations. By contrast, in characterizing the UNTOC Review Mechanism as "non-adversarial" and "inter-governmental," the states parties to UNTOC have signaled their disinterest in subjecting themselves to substantial pressure by civil society, peer states, or international organizations. UNTOC's states parties have also signaled their disinterest in the relatively coercive approach adopted by the Financial Action Task Force (FATF), which publicly rates states' compliance with its forty Recommendations on money laundering and the financing of terrorism and proliferation. ${ }^{55}$ In addition, FATF takes a fairly punitive approach toward noncomplying states. FATF issues "Public Statements" (also known as "blacklists"), which identify states with weak measures for combating money laundering and terrorist financing and in the worst cases it calls on FATF members and other jurisdictions to apply enhanced due diligence measures or

\footnotetext{
${ }^{51}$ Convention on Combating Bribery of Foreign Public Officials in International Business Transactions, Nov. 21, 1997, 37 ILM 1 (1998, entered into force Feb. 15, 1999) (OECD Anti-Bribery Convention).

52 Procedures and Rules for the Functioning of the Mechanism for the Review of the Implementation of the United Nations Convention Against Transnational Organized Crime and the Protocols Thereto, para. 4 [hereinafter Procedures and Rules for the Review Mechanism].

${ }^{53} I d$., para. 4(a).

${ }^{54} I d$., para. 4(a), (b), (f), (k)-(l).

55 FATF, Consolidated Assessment Ratings (Apr. 17, 2019), available at http://www.fatf-gafi.org/media/fatf/ documents/4th-Round-Ratings.pdf.
} 
"counter-measures" in relation to noncompliant jurisdiction(s). ${ }^{56}$ Although UNTOC's money laundering provision (Article 6) is closely related to FATF's money laundering standards, the UNTOC Conference of the Parties has distanced the Review Mechanism from FATF and its relatively coercive working methods.

The Conference of the Parties ultimately settled on a twelve-year program of reviews for all states parties, which covers UNTOC and the three protocols over the course of four phases. ${ }^{57}$ Each phase covers a particular set of provisions on topics such as criminalization, international cooperation, etc. ${ }^{58}$ The phases begin with a self-assessment questionnaire to be completed by the state party under review. ${ }^{59}$ States provide answers to the questionnaire via a knowledge management portal hosted by UNODC, known as SHERLOC (Sharing Electronic Resources on Laws and Crime). ${ }^{60}$ On the basis of this questionnaire, two peer reviewing countries conduct a "desk-based" review of the state party, without the benefit of a country visit. ${ }^{61}$ Following this desk-based review, the review team produces a country review report, which it submits to the Conference of the Parties' thematic working groups (which cover trafficking in persons, smuggling of migrants, and firearms). Once 70 percent of reviews in a given phase are complete, the review process may proceed to the next phase. ${ }^{62}$ All of the documents produced during this review process (i.e., the self-assessment questionnaire, the country review report, and the executive summary) remain confidential unless the state under review opts to make them public. ${ }^{63}$ Although the same rule applied to documents produced through UNCAC's review process, many states parties have agreed to make their country reports available, such that a significant amount of information about implementation and enforcement is public, despite this default confidentiality rule. ${ }^{64}$ It remains to be seen whether states parties to UNTOC will take a similar approach to the release of information about compliance.

With respect to the issue of civil society participation, the Conference of the Parties struck a compromise that only marginally enhances their role in the UNTOC review process, as compared to the participation of civil society in the UNCAC Review Mechanism. ${ }^{65}$ Most significantly, following the sessions of each of the thematic working groups, civil society may take part in what have been termed "constructive dialogues." These constructive dialogues have an inherently limited role, however, insofar as the dialogues take place after the working groups have already adopted their reports. ${ }^{66}$ Civil society is therefore excluded from the thematic working groups' most significant substantive deliberations. Moreover, during the




constructive dialogues, no specific country situation may be mentioned, although a state may, of its own accord, raise issues concerning its own review. ${ }^{67}$ In addition, at the self-assessment stage of the review process, states parties are "encouraged" but not required to consult with all relevant stakeholders (e.g., NGOs, academia, and the private sector). ${ }^{68}$ Finally, as is the case with the UNCAC Review Mechanism, civil society may also participate in the plenary sessions of the Conference of the Parties. ${ }^{69}$

With respect to the issue of funding, the Conference of the Parties agreed to limit the funds for the Review Mechanism to funds already allocated in the UN regular budget to the UNTOC Conference of the Parties. ${ }^{70}$ States parties may, however, opt to make additional voluntary contributions. ${ }^{71}$ Given that the UNTOC Review Mechanism does not involve country visits, it can be expected both to cost less and to impose less of a burden on states parties than the UNCAC Review Mechanism. The Conference of the Parties also sought to reduce the burden on reporting states by allowing them to refer to relevant information already submitted as a part of UNCAC's Review Mechanism. ${ }^{72}$ Given that a significant number of provisions in the two treaties are identical or nearly identical, some reusing of information is not only efficient, but also seemingly inevitable.

Given that UNTOC's Review Mechanism is not yet operational as of the time of this writing, a full-fledged assessment of its normative legitimacy would be premature. Its exact working methods are in development and it has not yet produced any country reports or other documents. Nevertheless, certain features of the Review Mechanism's design allow for some preliminary observations about its authority as an institution, and in particular its input-based legitimacy, meaning the processes by which it will take decisions. ${ }^{73}$ Assessments of institutions' input-based legitimacy typically focus, in part, on the transparency of deliberations and processes, as well as the inclusion of interested actors in those deliberations and processes. These factors are related to each other in that participation may depend partly on access to information, in addition to access to meetings, etc. The documents produced through the UNTOC review process will be inaccessible to the public, at least by default, and participation by interested actors, namely civil society, will be quite limited. As a result of the Review Mechanism's relative nontransparency and exclusiveness, its deliberations and decision-making processes may not benefit from all relevant information and views about the treaty's implementation, to the detriment of its normative legitimacy. The

${ }^{67}$ Id., para. 53(b).

68 Id., para. 23.

69 See Rules of Procedure of the Conference of States Parties to the United Nations Convention Against Corruption, supra note 41.

70 Procedures and Rules for the Review Mechanism, supra note 52, para. 54.

${ }^{71} \mathrm{Id}$.

72 Id., para. 22.

${ }^{73}$ See Fritz W. Scharpf, Economic Integration, Democracy and the Welfare State, 4 J. Eur. Pub. POL'y 18 (2007); Fritz Scharpf, Governing in Europe: Effective and Democratic (1999); Daniel Bodansky, Legitimacy in International Law and International Relations, in INTERDISCIPLINARY PERSPECTIVES ON INTERNATIONAL LAW AND International Relations: The State of the Art 321 (Jeffrey L. Dunoff \& Mark A. Pollack eds., 2013); Geir Ulfstein, The Human Rights Treaty Bodies and Legitimacy Challenges, in LEGITIMACY AND INTERNATIONAL Courts 284 (Nienke Grossman, Harlan Grant Cohen, Andreas Føllesdal \& Geir Ulfstein eds., 2018); Benedict Kingsbury, Nico Krisch \& Richard B. Stewart, The Emergence of Global Administrative Law, 68 L. \& Contemp. Probs. 15 (2005); Allen Buchanan \& Robert O. Keohane, The Legitimacy of Global Governance Institutions, 20 ETH. \& INT'L AfF. 405 (2006). 
Review Mechanism's lack of transparency and inclusiveness may also impact its output-based legitimacy, meaning the results of its treaty monitoring efforts. By limiting civil society's access to the results of the review process, the ability of NGOs and other actors to contribute to efforts to combat organized crime may be hampered, thereby limiting the Review Mechanism's effectiveness as an institution.

\section{Explaining the Controversies and the Delay}

Now that the Conference of the Parties has finally resolved the controversies surrounding UNTOC's Review Mechanism, the question is why such a compromise was unattainable for so many years. This Part considers a number of factors that together may explain the apparent resistance to or disinterest in the creation of a Review Mechanism for the Convention: the marginal status of criminal justice issues within the UN system, states' resistance to external scrutiny of their criminal justice systems, and the limited history of treaty monitoring in the field of transnational criminal law.

\section{Criminal Justice Issues Within the UN System}

Controversies surrounding the creation of an UNTOC Review Mechanism may reflect a broader resistance to bringing criminal justice matters squarely within the remit of the United Nations, and to giving UN bodies a robust role in overseeing domestic criminal justice systems. ${ }^{74}$ Resistance to the creation of a Review Mechanism for UNTOC may, in other words, be understood partly as a reflection of the relatively low priority of criminal justice issues within the UN system. ${ }^{75}$ Issues of domestic criminal justice have traditionally fallen within the domaine reservé of states, and did not become the subject of extensive international lawmaking until after World War II. Even following the establishment of the United Nations in 1945 , states continued to view criminal justice issues as internal affairs of the state, in particular socialist countries such as the former USSR. ${ }^{76}$ To this day, states' concerns about their national sovereignty and noninterference in domestic affairs continue to represent "the most significant barriers to the development of transnational criminal law." 77

Despite these obstacles, a significant number of multilateral agreements now cover a wide range of transnational crimes, although these treaties have been concluded in a highly ad hoc manner, and for the most part outside of the auspices of the United Nations (UNTOC and UNCAC are two of five exceptions). ${ }^{78}$ Within the UN system, many different bodies have

${ }^{74}$ Mark Shaw \& Julia Stanyard, Convention Facing Political Cul-de-Sac, Global Initiative Against Transnational Organized Crime (May 14, 2018), Glob. Initiative Against Transnat'l Organized CRIME, at https://globalinitiative.net/convention-facing-political-cul-de-sac.

75 Овоката, supra note 45, at 214.

76 SŁawomir Redo, Blue Criminology: The Power of United Nations Ideas to Counter Crime Globally 110 (2012).

77 BoISTER, supra note 7 , at p35.

78 Sławomir Redo, The United Nations Criminal Justice System in the Suppression of Transnational Crime, in Routledge Handbook of Transnational Criminal Law 57 (Neil Boister \& Robert J. Currie eds., 2015). The other three UN treaties deal with drug control issues. Single Convention on Narcotic Drugs, 1961, as Amended by the 1972 Protocol, Mar. 30, 1961, 520 UNTS 151 (entered into force Dec. 13, 1964); Convention on Psychotropic Substances (with lists of Substances), Feb. 21, 1971, 1019 UNTS 175 (entered into force Aug. 16, 1976); United Nations Convention Against Illicit Traffic in Narcotic Drugs and Psychotropic Substances (with Annex), Dec. 20, 1988, 1582 UNTS 95 (entered into force 1990). 
mandates that relate to transnational crimes, which has resulted in both fragmentation and duplication of programming. ${ }^{79}$ Furthermore, while criminal justice issues fall within the competence of the General Assembly, its focus on organized crime has been limited and sporadic. ${ }^{80}$ This may reflect, in part, the fact that organized crime typically does not trigger the sort of high-profile crises that require urgent responses, but instead causes more ongoing, less dramatic harm (with the exception, for example, of the Mediterranean migration crisis beginning in 2015). ${ }^{81}$

The low priority of criminal justice issues within the United Nations is further evidenced by the relatively minimal funds allocated in the regular UN budget for the Office on Drugs and Crime in Vienna. ${ }^{82}$ In 2018-2019, UNODC was allocated USD 25 million from that budget, ${ }^{83}$ whereas, by contrast, the UN Office of the High Commissioner for Human Rights in Geneva was allocated USD 201.6 million in regular budget appropriations. ${ }^{84}$ The debates within the UNTOC Conference of the Parties about funding the review mechanism therefore reflect a broader unwillingness to allocate more funding to UNODC, and thus a higher priority to criminal justice issues within the UN system.

Not only do criminal justice issues have relatively low priority within the UN system, but organized crime in particular waned in political importance following the terrorist attacks of September 11, 2001, which occurred after the adoption of UNTOC in 2000 but before it came into force in 2003. ${ }^{85}$ Thus in the early 2000s, just when UNTOC might have gained momentum, the UN General Assembly's attention instead shifted away from organized crime and toward terrorism. ${ }^{86}$ This explanation, however, does not account for the fact that states nevertheless managed to conclude UNCAC and establish a Review Mechanism for it, all in the aftermath of $9 / 11$.

On a more speculative note, the low priority of criminal justice issues within the UN system may also be a consequence of the great prominence or political sensitivity of criminal justice issues at the domestic level. Legal approaches to organized crime may, in particular, be politically sensitive because of the phenomenon of state organized crime. State actors, for example, have actively participated in human trafficking, migrant smuggling, and drug

\footnotetext{
${ }^{79}$ Summer Walker \& Tuesday Reitano, Fragmented but Far-Reaching: The UN System's Mandate and Response to Organized Crime, Glob. Initiative Against Transnat'l Organized Crime (June 2019), available at https:/globalinitiative.net/wp-content/uploads/2019/06/gitoc_un_june_19.pdf.

${ }^{80}$ Paulette Lloyd, Beth A. Simmons \& Brandon M. Stewart, Combating Transnational Crime: The Role of Learning and Norm Diffusion in the Current Rule of Law Wave, in RULE OF LAW DyNAMICS: IN AN ERA OF International and Transnational Governance 153, 155 (Michael Zürn, André Nollkaemper \& Randy Peerenboom eds., 2010).

${ }^{81}$ Walker \& Reitano, supra note 79 , at 2.

${ }^{82}$ ОвокатA, supra note 45 , at 213.

${ }^{83}$ Budget for the Biennium 2018-2019 for the United Nations Crime Prevention and Criminal Justice Fund, Res. 26/5. The total budget for the UN Crime Prevention and Criminal Justice Fund for 2018-2019 is USD 332.6 million. Voluntary contributions and other revenue are projected to account for USD 2.9 million in general-purpose funds and USD 304.7 million in special-purpose funds. Id. See also BoIsTer, supra note 7, at 398.

${ }^{84}$ United Nations Office of the High Commissioner for Human Rights, UN Human Rights Report 2017, at 77, available at https://www2.ohchr.org/english/OHCHRreport2017/allegati/5_Funding_2017.pdf.

${ }^{85}$ Peter Gastrow, Adopted 18 Years Ago, Why Has the UNTOC Still Not Achieved Its Aim?, GLoB. InITIATIVE Against Transnat'l Organized Crime (Mar. 20, 2018), at https://globalinitiative.net/adopted-18-years-agowhy-has-the-untoc-still-not-achieved-its-aim.

${ }^{86}$ For a visual representation of this, see Lloyd, Simmons \& Stewart, supra note 80, at 155.
} 
trafficking. ${ }^{87}$ UNTOC itself, however, conceives of organized crime as a private sector phenomenon and does not acknowledge or address state involvement in organized crime, beyond passive bribery by a state official. The Convention was not intended to address the possibility that government officials could themselves form an organized criminal group that engages in the type of conduct that UNTOC covers when carried out by private actors. A significant gap therefore exists between the Convention and its Protocols and the reality of the "shadow state." 88 A significant number of states may not wish to draw attention to this discrepancy, and to see government officials' involvement in organized crime become the subject of external deliberations or scrutiny, whether in the UN General Assembly, or within the context of the UNTOC Review Mechanism. The Conference of the Parties' resistance to creating an inclusive, transparent, and well-funded review process may therefore be seen, in part, as the result of sensitivities about state involvement in the very conduct that these instruments aim to combat.

\section{Treaty Monitoring in the Field of Transnational Criminal Law}

The controversies and delays involved in creating the UNTOC Review Mechanism may also be attributed, in part, to the relative absence of treaty monitoring bodies in the field of transnational criminal law. ${ }^{89}$ While treaty monitoring is a standard feature of treaties in other branches of public international law, such as human rights law and environmental law, this is not the case with respect to transnational criminal law treaties. ${ }^{90}$ The UNCAC Review Mechanism and the International Narcotics Control Board (INCB), which monitors compliance with the drug control treaties, are the exception rather than the norm. The UN Security Council's Counter-Terrorism Committee (CTC) has also monitored implementation of terrorism conventions (e.g., the Terrorism Financing Convention), but these treaty monitoring efforts have fundamentally different origins than the UNCAC Review Mechanism and the INCB. The monitoring of terrorism conventions does not stem from the text of the terrorism treaties, which do not provide for the creation of a treaty monitoring body or any form of formal follow-up. Instead, these treaty monitoring efforts originate in UN Security Council resolutions adopted following the terrorist attacks of $9 / 11 .{ }^{91}$

The UNTOC Conference of the Parties therefore approached the subject of a review mechanism without the benefit of a long line of established precedent that would have made the path forward more obvious, and its decision making more straightforward. The INCB, the UNCAC Review Mechanism, and the CTC embody different forms of treaty monitoring.

${ }^{87}$ See, e.g., Philippa Webb \& Rosana Garciandia, State Responsibility for Modern Slavery: Uncovering and Bridging the Gap, 68 Int'l \& Comp. L. Q. 539 (2019); Henri Decoeur, Confronting the Shadow State: an International Law Perspective on State Organized Crime 15-41 (2018)

${ }^{88}$ Decoeur, supra note 87 , at 148-50.

${ }^{89}$ Cecily Rose, Treaty Monitoring and Compliance in the Field of Transnational Criminal Law, 2 BRILL Res. Perspec. Transnat'l Crime 40 (2018).

${ }^{90}$ Cosette D. Creamer \& Beth A. Simmons, The Proof Is in the Process: Self-Reporting Under International Human Rights Treaties, 114 AJIL 1 (2020).

${ }^{91}$ SC Res. 1373, para. 6 (2001) (creating a Committee of the Security Council, consisting of all members of the Council, to monitor implementation of the resolution); SC Res. 1535 (2004) (creating the Counter-Terrorism Committee Executive Directorate (CTED). See e.g., Isobel Roele, Disciplinary Power and the UN Security Council Counter Terrorism Committee, 19 J. ConflICT \& SEC. L. 49 (2013); Andrea Bianchi, Security Council's Anti-Terror Resolutions and Their Implementation by Member States, 4 J. InT'L CRIM. Just. 1044 (2006). 
While the INCB and the CTC Executive Directorate are expert bodies that carry out reviews themselves, the UNCAC Review Mechanism operates on the basis of peer review, with states parties reviewing each other. ${ }^{92}$ In the early years of negotiations (2008-2010), the UNTOC Conference of the Parties devoted time to surveying the various models and assessing its options. ${ }^{93}$ Such an exercise would be unnecessary, by comparison, in the field of human rights in which all treaty bodies follow the same basic structure and working methods. Likewise, the creation of an UNCAC Review Mechanism may not have been impeded by an absence of precedent because a number of anti-corruption treaties, concluded before UNCAC, benefit from peer review monitoring mechanisms, most notably the OECD's Working Group on Bribery.

UNCAC's Review Mechanism ultimately served as both the most relevant precedent for UNTOC's Review Mechanism, and as a sort of cautionary tale that may have had a chilling effect that contributed to prolonging negotiations. Because of the substantive similarities between UNTOC and UNCAC, UNCAC's Review Mechanism unsurprisingly provided the most relevant template for UNTOC's Review Mechanism. But the costliness and burdensomeness of UNCAC's Review Mechanism resulted in some states strongly resisting the replication of such a body for UNTOC. The decision taken by UNTOC's Conference of the Parties to omit country visits from the review process stems from the unwillingness of some states to devote a similar amount of time, money, and people to yet another treaty review process.

The omission of country visits from UNTOC's review process, however, could significantly diminish the Review Mechanism's capacity to bring about improved implementation with the Convention. Anecdotal information suggests that the country visits carried out within UNCAC's review process may have helped to trigger law reform efforts by the country under review. In other words, the prospect of a visit by a team of reviewers seems to have prompted some states to draft or pass implementing legislation before the scheduled country visit takes place (but after the completion of the self-assessment questionnaire). If future research shows a correlation between scheduled country visits and law reform efforts on a cross-national, rather than merely anecdotal basis, then the absence of country visits for UNTOC may take on added significance. In other words, UNTOC's Review Mechanism may be at a structural disadvantage with respect to its capacity to bring about implementation among states parties.

\footnotetext{
92 The INCB consists of thirteen individuals who are elected by the Economic and Social Council and serve in their personal capacity for terms of five years. Single Convention on Narcotic Drugs, 1961, as Amended by the 1972 Protocol, , Art. 9(1)-(2), 976 UNTS 105 (entered into force Aug. 8, 1975). The CTED, by contrast, consists of approximately forty UN staff members who serve in their official, rather than personal capacity. When the CTED conducts country visits, the delegations consist of representatives from CTED, other UN entities, and other non-UN bodies, such as FATF-Style Regional Bodies. International Federal for Human Rights (FIDH), The United Nations Counter-terrorism Complex: Bureaucracy, Political Influence and Civil Liberties 32-33 (2017), at https://www.fidh.org/en/international-advocacy/united-nations/united-nations-the-global-fightagainst-terrorism-hampered-by.

93 See, e.g., Comparative Analysis of Existing Review Mechanisms, supra note 33.
} 


\section{Conclusion}

The creation of a Review Mechanism for UNTOC, after so many years of controversy, is undoubtedly a noteworthy accomplishment for the Conference of the Parties, although the Review Mechanism is, in many ways, less than ideal. Controversies about the participation of civil society, sources of funding, and, to a lesser extent, the burdensomeness of this review process, predictably resulted in a flawed Review Mechanism that is the product of a number of significant compromises. The Mechanism's funding is not only relatively limited but also unpredictable, civil society participation is highly circumscribed, the review process excludes country visits, and the review documents are, by default, confidential. Moreover, UNTOC's Review Mechanism imposes yet another reporting obligation on states that are already burdened by many other treaty reporting obligations.

Despite the Review Mechanism's considerable flaws, it nevertheless holds the potential to facilitate a better understanding of UNTOC's influence in practice. If a significant number of states parties opt to make country reports publicly available, as has been the case with the UNCAC country reports, this will create a significant body of data about whether and how states are implementing and potentially also enforcing UNTOC. Without such data, both researchers and the Conference of the Parties remain largely in the dark about what kind of influence, if any, this treaty is having within domestic legal systems and with respect to international cooperation in the investigation and prosecution of organized crime. Given that UNTOC has been in force for more than fifteen years, an assessment of compliance and technical assistance needs is long overdue. The Review Mechanism may ultimately enable an evaluation of whether UNTOC and its three protocols just represent a massive international lawmaking effort, or an active part of the fight against organized crime. 